\title{
Dutch dairy farms after milk quota abolition: Economic and environmental consequences of a new manure policy
}

\author{
C. W. Klootwijk, ${ }^{* 1}$ C. E. Van Middelaar, ${ }^{*}$ P. B. M. Berentsen, $†$ and I. J. M. de Boer* \\ *Animal Production Systems Group, Wageningen University, PO Box 338, 6700 AH Wageningen, the Netherlands \\ †Business Economics Group, Wageningen University, PO Box 8130, 6700 EW Wageningen, the Netherlands
}

\begin{abstract}
The abolition of the Dutch milk quota system has been accompanied by the introduction of a new manure policy to limit phosphate production (i.e., excretion via manure) on expanding dairy farms. The objective of this study was to evaluate the effect of these recent policy changes on the farm structure, management, labor income, nitrogen and phosphate surpluses, and greenhouse gas emissions of an average Dutch dairy farm. The new manure policy requires that any increase in phosphate production be partly processed and partly applied to additional farmland. In addition, phosphate quotas have been introduced. Herein, we used a wholefarm optimization model to simulate an average farm before and after quota abolition and introduction of the new manure policy. The objective function of the model maximized labor income. We combined the model with a farm nutrient balance and life-cycle assessment to determine environmental impact. Based on current prices, increasing the number of cows after quota abolition was profitable until manure processing or additional land was required to comply with the new manure policy. Manure processing involved treatment so that phosphate was removed from the national manure market. Farm intensity in terms of milk per hectare increased by about $4 \%$, from $13,578 \mathrm{~kg}$ before quota abolition to $14,130 \mathrm{~kg}$ after quota abolition. Labor income increased by $€ 505 / \mathrm{yr}$. When costs of manure processing decreased from $€ 13$ to $€ 8 / \mathrm{t}$ of manure or land costs decreased from $€ 1,187$ to $€ 573 /$ ha, farm intensity could increase up to $20 \%$ until the phosphate quota became limiting. Farms that had already increased their barn capacity to prepare for expansion after milk quota abolition could benefit from purchasing extra phosphate quota to use their full barn capacity. If milk prices increased from $€ 355$ to $€ 420 / \mathrm{t}$, farms could grow unlimited, provided that the availability of external inputs such as labor, land, barn capacity, feed, and phosphate quota at current prices were also unlimited. The milk quota aboli-
\end{abstract}

Received December 18, 2015.

Accepted June 16, 2016.

${ }^{1}$ Corresponding author: Cindy.Klootwijk@wur.nl tion, accompanied by a new manure policy, will slightly increase nutrient losses per hectare, due to an increase in farm intensity. Greenhouse gas emissions per unit of milk will hardly change, so at a given milk production per cow, total greenhouse gas emissions will increase linearly with an increase in the number of cows.

Key words: Dairy Act, farm expansion, phosphate quota, manure processing

\section{INTRODUCTION}

In 1984, milk quotas were introduced in Europe to address oversupply in the market. The quota policy restricted the amount of milk to be produced by each member state and, consequently, by individual farmers. In April 2015, the European Union (EU) milk quota system was abolished in response to the increasing global demand for milk and to agreements on trade liberalization in global dairy markets (EU, 2015). The abolition of the quota system allows farmers to increase their milk production and is expected, therefore, to increase milk production in most EU countries (Lips and Rieder, 2005).

Livestock density in the Netherlands is the highest in Europe. This is due to the central location of the Netherlands in western Europe, where the demand for livestock products is high, combined with easy import of feed due to close proximity to the harbor of Rotterdam. This high livestock density, however, also results in high production (i.e., excretion via manure) of nitrogen and phosphate per hectare, which causes environmental problems such as eutrophication of ground and surface water (Oenema et al., 2005). Moreover, the livestock sector, including dairy production, is one of the main contributors to greenhouse gas (GHG) emissions (Gerber et al., 2013). The expected increase in milk production per farm due to quota abolition might increase the environmental impact of dairy production.

To limit nitrate leaching from agricultural production to ground and surface water, the European Nitrates Directive was introduced (EU, 1991), imposing a maximum application of $170 \mathrm{~kg}$ of $\mathrm{N}$ from animal manure per hectare. Within this directive, 7 member states, including the Netherlands, obtained a derogation to go 
beyond the 170-kg limit, under certain country-specific conditions. One such condition for the Netherlands is a phosphate production ceiling of 172.9 million $\mathrm{kg} /$ yr for the entire Dutch livestock sector, including a phosphate production ceiling of 84.9 million $\mathrm{kg} / \mathrm{yr}$ for the dairy sector. To accommodate this phosphate ceiling, the Dutch government introduced a new manure policy. This "Dairy Act" of 2015 is aimed at supporting the growth of the Dutch dairy sector while limiting increases in phosphate production.

Abolition of the milk quota and introduction of the Dairy Act might change the Dutch dairy sector. Changes in farm structure and management can affect a farmer's income and the environmental impact of dairy production. Several studies have analyzed the effect of quota abolition on the economic and environmental performance of the dairy sector, most using macroeconomic models and analyzed effects at region or country level (Lips and Rieder, 2005; Kempen et al., 2011). Kempen et al. (2011), for example, predicted a loss in overall agricultural income, and an increase in environmental effects (e.g., nitrate leaching and methane emission) related to an expanding dairy herd in large parts of Europe, especially the Netherlands. To our knowledge, however, the effect of the quota abolition in combination with the introduction of the Dairy Act is unknown. Moreover, we found no studies that took a farm-level perspective and considered changes in farm management in response to changes in policy.

The objective of this study, therefore, was to evaluate the effect of quota abolition and introduction of the Dairy Act on the structure, management, and labor income of a Dutch dairy farm. In addition to these effects, we also considered changes in environmental impact (i.e., nitrogen and phosphorus losses, and GHG emissions). To determine the economic and environmental impact, we combined a whole-farm linear programming model with a farm nutrient balance and life-cycle assessment. We have illustrated strategies for an average Dutch dairy farm on sandy soil. To understand the current political context, we first describe milestones in Dutch environmental policy.

\section{MATERIALS AND METHODS}

\section{Milestones in Dutch Environmental Policies Before Quota Abolition}

Since about 1980, policies have been aimed at regulating the environmental impact of Dutch agricultural production, including dairy production (Oenema and Berentsen, 2005). A first milestone in environmental policy was the introduction of phosphate application standards in 1987. These standards were based on fixed phosphate excretions per type of animal and set limits on the application of phosphate from animal manure per hectare of grassland or crop land (Berentsen and Tiessink, 2003). Farmers exceeding these standards had to pay a levy. Introduction of phosphate application standards, however, barely reduced nutrient losses from agriculture, because application standards and levies were so generous that dairy farms were essentially unaffected (Berentsen et al., 1992).

A second milestone occurred with the introduction of the European Nitrates Directive (EU, 1991), aimed at reducing the negative effects of nitrogen surpluses on water quality. This directive shifted the focus from phosphate to nitrogen. To ensure compliance with the nitrates directive, the Netherlands introduced the mineral accounting system (MINAS) in 1998; MINAS was based on a farm-gate balance approach, using farm-level inputs and outputs to determine a farmspecific surplus of nitrogen and phosphate (Oenema and Berentsen, 2005). Nutrient surpluses at the farm level that exceeded levy-free surpluses were charged. The MINAS system was considered a step forward in environmental policy, because nutrient surpluses are better indicators of nutrient leaching than manure application standards, and because MINAS gave farmers the autonomy to determine how to reduce their surplus.

A judgment of the European court (EU, 2003) about MINAS's lack of compliance with the nitrates directive, in combination with other practical reasons such as increasing administrative burdens and possibilities of fraud, led to the abolition of MINAS in 2006 and the introduction of 3 fertilizer application standards - the third milestone. The first standard comprises a maximum application of $170 \mathrm{~kg}$ of $\mathrm{N}$ from animal manure per hectare of land. Several member states, including the Netherlands, obtained a derogation to go beyond the $170-\mathrm{kg}$ limit, under certain country-specific conditions. Derogation is specific for these member states because they have a high proportion of grassland and a relatively long growing season, justifying a higher nutrient uptake (EU, 2010). Current derogation regulation in the Netherlands prescribes that farms with at least $80 \%$ grassland are allowed to apply, depending on soil type and region, $250 \mathrm{~kg}$ of $\mathrm{N}$ from animal manure per hectare on all of their land. Farmers who receive this derogation are not allowed to use synthetic phosphate fertilizer. To receive derogation for 2014-2017, the Netherlands must comply with a phosphate production ceiling of 172.9 million $\mathrm{kg} / \mathrm{yr}$ and a nitrogen production ceiling of 504.4 million $\mathrm{kg} / \mathrm{yr}$ for the entire Dutch livestock sector. The second standard comprises a maximum application of nitrogen fertilizer per hectare of land, including mineral nitrogen from manure, and accounts for nitrogen fixation, deposition, and miner- 
alization. The third standard comprises a maximum application of phosphate fertilizer per hectare of land, including phosphate from manure. Although the first and second standards overlap to a degree, all 3 apply to every Dutch dairy farm. The application standards for nitrogen and phosphate fertilization have been decreased several times over the past decade. Farmers exceeding these standards can be brought to court.

\section{Additional Policy After Quota Abolition}

To comply with the phosphate production ceiling set by the EU as a condition for derogation, the Dutch government prescribed the dairy sector a phosphate production ceiling of 84.9 million $\mathrm{kg} / \mathrm{yr}$ based on production levels in 2002. In 2014, however, this limit was exceeded by 0.7 million $\mathrm{kg}$ of phosphate (CBS, 2015). To limit further growth as a result of the quota abolition, a new manure policy, referred to as the "Dairy Act," was adopted in December 2014 as a framework law. The Dairy Act prescribes routes for handling the phosphate surplus at the farm level and limits an increase in phosphate production at the sector level. The concrete content of this law consists of 3 parts that have been developed over time based on progressive insight. Figure 1 shows the implications of these 3 parts for a farm, of which the area remains constant but the number of animals increases.

The starting situation is given by the reference phosphate surplus of a farm in 2013, defined as the production minus the application room (surplus $\mathrm{A}$ in Figure 1). Phosphate production is defined here as the number of livestock $\times$ fixed phosphate excretions per type of livestock (Appendix Table A1), and phosphate application room as the number of hectares $\times$ the phosphate application standards. Previous legislation stipulated that part of the reference surplus should be processed based on region-specific rules (i.e., $30 \%$ in the south, $15 \%$ in the east, and $5 \%$ in other regions of the Netherlands; Nitraatrichtlijn, 2014); the remaining part can be disposed to other Dutch farms with application room.

The first part of the Dairy Act, developed in 2014 and introduced in 2015, indicated that any increase in phosphate surplus on top of the reference surplus needed to be fully processed. Manure processing involves treating the manure so that phosphate is removed from the national manure market, which can be done by destruction (incineration or gasification to ash), treatment, or export. When the second part of the Dairy Act was developed in 2015, a maximum was set to the volume of the extra phosphate surplus that may be fully processed (surplus B in Figure 1). This maximum was determined by the phosphate production of a farm in 2014.

The second part of the Dairy Act will be introduced in 2016. In an attempt to tie dairy production more closely to the use of land on the same farm, any phosphate surplus on top of surpluses A and B (surplus C in Figure 1) should be partly processed and partly applied to additional land that should be purchased or hired by the farm. Requirements related to the percentage of this surplus $\mathrm{C}$ for which extra land should be acquired depend on the level of the total phosphate surplus in

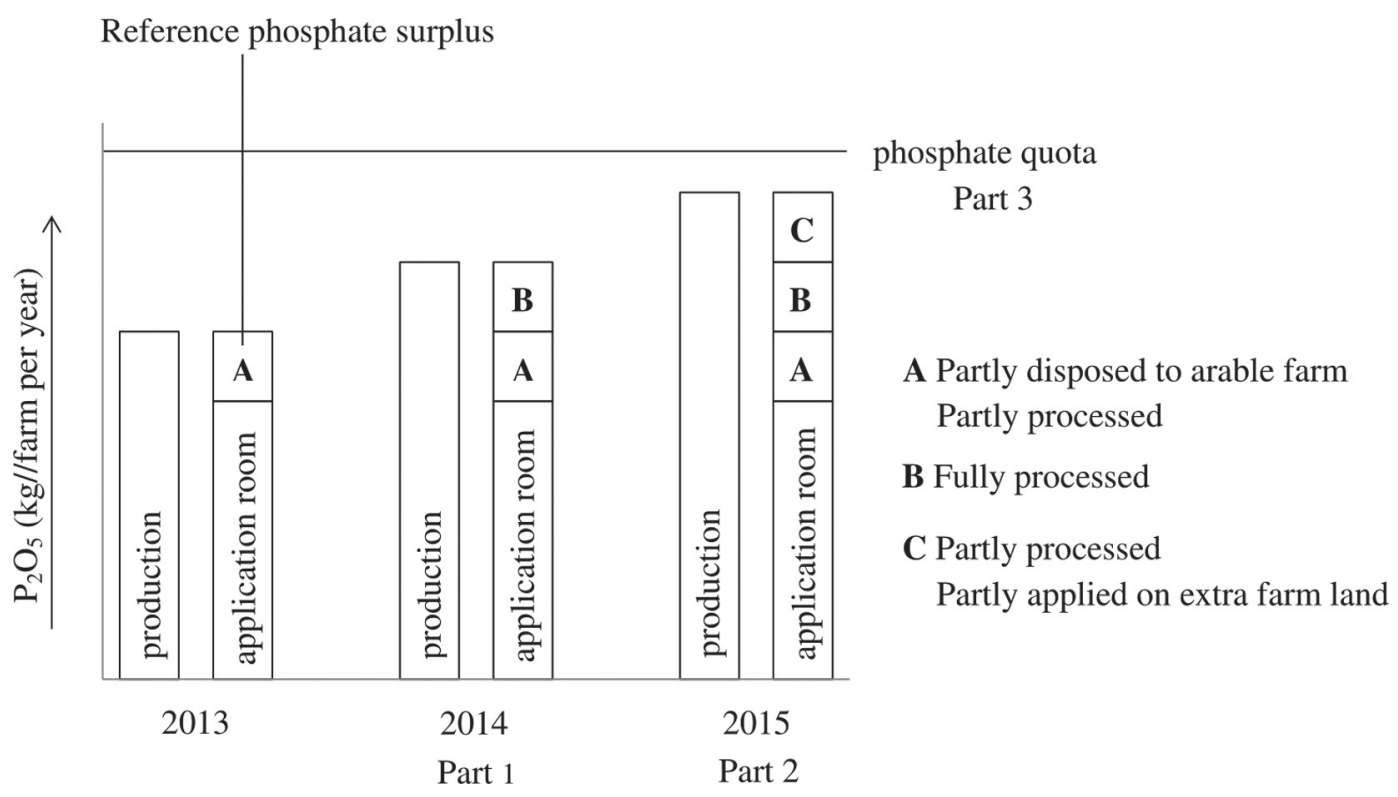

Figure 1. New Dutch manure policy after quota abolition (the "Dairy Act"). The total surplus of 2015 is based on farm-specific excretion factors, whereas calculation of surpluses A, B and the phosphate quota are based on standard excretion factors per type of animal. 
the year of analysis ( $0 \%$ if the surplus is $<20 \mathrm{~kg} \mathrm{ha}^{-1}$, $25 \%$ if the surplus is 20 to $50 \mathrm{~kg} \mathrm{ha}^{-1}$, and $50 \%$ if the surplus is $>50 \mathrm{~kg} \mathrm{ha}^{-1}$; Rijksoverheid, 2015).

Because signals indicated that phosphate production in the dairy sector would grow considerably in spite of the new manure policy, the Dutch government announced a third part of the Dairy Act in July 2015. This part consists of a phosphate quota at the farm level to restrict total Dutch phosphate production to comply with the national production ceiling of 172.9 million $\mathrm{kg} / \mathrm{yr}$ set by the EU. Each farm is assigned a farm-specific phosphate production quota based on the average number of cows on the farm in July 2015 and standard excretion factors (RVO, 2014). The date that this new quota system was announced and the counting date with regard to the number of animals on the farm were aligned to avoid farmers anticipating this new legislation. Quotas can be transferred between dairy farms.

Whereas calculation of surpluses A, B, and the phosphate quota are based on standard excretion factors per type of animal, the actual phosphate surplus in the year of analysis can be based on farm-specific excretion factors.

This overview of milestones in Dutch environmental policies shows that dairy farmers continuously have to anticipate uncertainties and changes in regulations. This study aims to evaluate the effect of the most recent policy changes, including the abolition of the milk quota and introduction of the Dairy Act, on the structure, management, and labor income of a Dutch dairy farm. Changes in environmental impact, including losses of nitrogen and phosphate and emission of GHG emissions are considered as well.

\section{Dairy Farm Model}

We used a dairy farm optimization model to simulate a Dutch dairy farm before and after quota abolition and the inclusion of the Dairy Act. The model was originally developed by Berentsen and Giesen (1995), but was recently updated by Van Middelaar et al. (2014). We also updated the prices and included the stipulations of the Dairy Act in the model. The objective function of the model maximized labor income, (i.e., gross returns minus variable and fixed costs). Important activities were on-farm feed production, purchase of feed, animal production, manure application, purchase and application of synthetic fertilizers, and field operations.

We assumed that the average cow in the model belonged to the Holstein Friesian breed and calved on February 1. Female young stock were kept for yearly replacement of the dairy herd, whereas male calves and surplus female calves were sold at an age of 2 wk. The model distinguished between summer and winter for feeding. Based on feed restrictions, the model matched the feed requirements of the cow with on-farm feed production and purchased feed. Feed requirements concerned energy, RDP balance, true protein digested in the small intestine, and phosphorus. In addition, DMI capacity was limited, based on Jarrige (1988). On-farm feed production included production of maize silage and production of grass for grazing and silage making. One hectare of silage maize yields $15.5 \mathrm{t}$ of $\mathrm{DM} / \mathrm{yr}$, which equals 102 GJ of $\mathrm{NE}_{\mathrm{L}}$ (CBS, 2013). Grassland yield depends on the level of nitrogen fertilization, which can vary from 100 to $500 \mathrm{~kg} /$ ha per year. Based on $225 \mathrm{~kg}$ of $\mathrm{N} /$ ha per year, 1 ha of grassland yields 66 GJ of $\mathrm{NE}_{\mathrm{L}} / \mathrm{yr}$. Purchased feeds included maize silage (to be ensiled by the farmer; KWIN-V, 2014) and 3 types of concentrates that differed in protein levels (i.e., standard, medium, and high). We updated the costs of farm inputs according to long-term expected market prices (KWIN-V, 2014). All dietary options were available in winter and summer, except for fresh grass (only available in summer). Table 1 shows the feed characteristics and prices of the available feed products. We determined farm-specific excretion based on inputs and outputs at herd level, represented by the average cow with young stock.

Constraints of the model included links between activities (e.g., between feeding requirements and produced and purchased feed, and between manure production/ application and environmental policies). Environmental policies, for example, include limits to the application of nitrogen and phosphate on the farm as explained before. According to the application standards for 2015-2017 (Nitraatrichtlijn, 2014), the maximum annual amount for mineral nitrogen on sandy soil is 250 $\mathrm{kg} / \mathrm{ha}$ for grassland and $140 \mathrm{~kg} / \mathrm{ha}$ for maize land, and the maximum annual amount for nitrogen from animal manure is $230 \mathrm{~kg} / \mathrm{ha}$ with derogation and $170 \mathrm{~kg} / \mathrm{ha}$ without derogation. For phosphate, the maximum annual amount is $90 \mathrm{~kg} / \mathrm{ha}$ for grasslands and $60 \mathrm{~kg} / \mathrm{ha}$ for maize land. The environmental impact calculations formed an integral part of the model and are explained in the next section.

\section{Environmental Impact}

A common method of quantifying losses of nutrients is the nutrient balance approach (Oenema et al., 2003). A nutrient balance computes the difference in nutrients entering and leaving a system, and can be used to quantify environmental indicators such as the nutrient surplus expressed per hectare of land or per unit of valuable output. This study used a farm-level nutrient balance to quantify nitrogen and phosphate surpluses 
Table 1. Feed characteristics and prices of available feed products

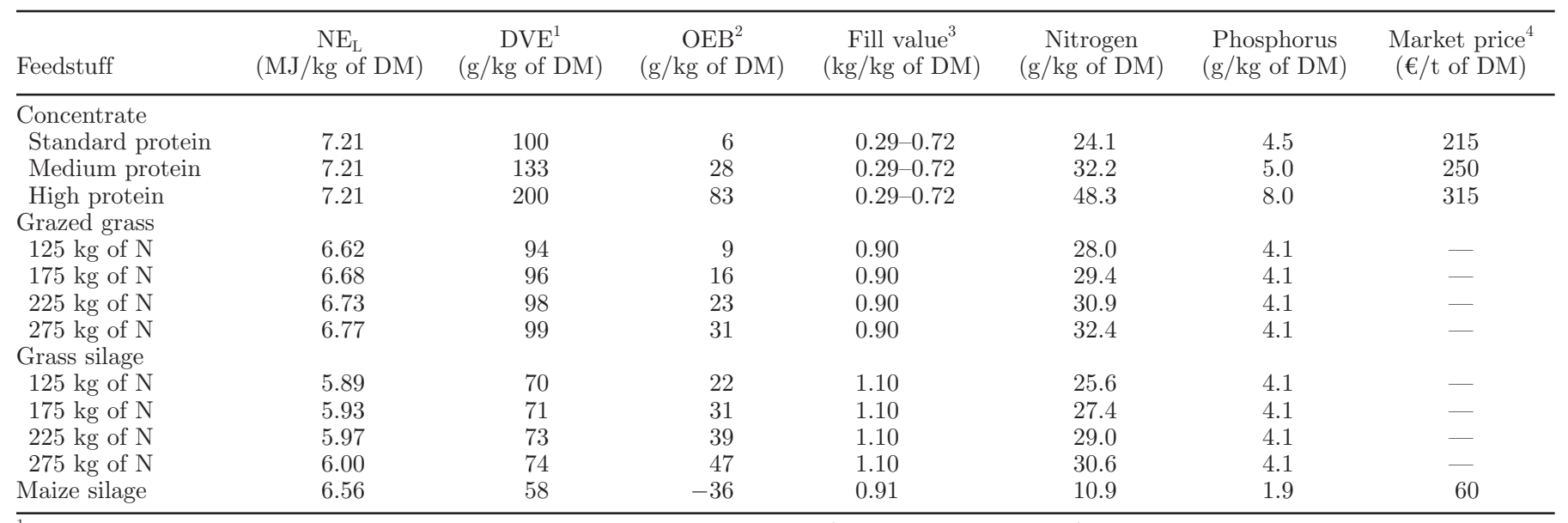

${ }^{1}$ True protein digested in the small intestine according to Dutch standards (Tamminga et al., 1994).

${ }^{2}$ Rumen-degradable protein balance according to Dutch standards (Tamminga et al., 1994).

${ }^{3}$ Fill value per kilogram of DM feed expressed in kilogram of a standard reference feed (Jarrige, 1988). The fill value of concentrates increases with an increase in concentrate intake.

${ }^{4}$ Applies only to purchased feed products (KWIN-V, 2014).

per hectare of on-farm agricultural area, as an indicator for the local environmental pressure related to nitrogen and phosphate losses. Inputs of nitrogen and phosphorus are in the form of concentrates, maize silage, fertilizer, and atmospheric deposition, whereas outputs are in the form of milk, culled animals, and, potentially, manure. A positive nitrogen balance implies that nitrogen is potentially lost to the environment through, volatilization of ammonia or nitrous oxide, or through runoff and leaching of dissolved nitrate, for example. A positive phosphate balance implies that phosphate can accumulate in the soil and is potentially lost to the environment through leaching and runoff, contributing to eutrophication of ground and surface waters (Sharpley, 1995).

In contrast to site-specific effects such as eutrophication, climate change is a global problem. To analyze the effect on climate change, therefore, changes in GHG emissions should be evaluated at the chain level, taking into account not only on-farm processes, but also other stages along the production chain (Van Middelaar et al., 2013). We used life-cycle assessment to evaluate emissions of the 3 major GHG related to agricultural production: carbon dioxide $\left(\mathrm{CO}_{2}\right)$, methane $\left(\mathrm{CH}_{4}\right)$, and nitrous oxide $\left(\mathrm{N}_{2} \mathrm{O}\right)$, from cradle to farm gate. Processes included were the extraction of raw materials to produce farm inputs, the manufacturing and distribution of these inputs, and all processes on the dairy farm.

Emission calculations have been described in detail by Van Middelaar et al. (2014). Emissions from the production and combustion of energy sources, and from production of synthetic fertilizer, pesticides, and tap water were based on Weidema et al. (2013). Emissions from the production of concentrates were updated (Appendix Table A2). We calculated enteric methane from dairy cows based on empirical relations between DMI of feed ingredients and methane emission factors per ingredient (FeedPrint, 2015). For young stock, we based enteric methane emission on Intergovernmental Panel on Climate Change (IPCC) tier 2 methods and default values (IPCC, 2006). Methods to calculate emissions from manure management, and from fertilizer application to the field, were derived from national reports (e.g., De Mol and Hilhorst, 2003).

Greenhouse gases were summed up based on their equivalence factor in terms of $\mathrm{CO}_{2}: 1$ for $\mathrm{CO}_{2}, 28$ for biogenic $\mathrm{CH}_{4}, 30$ for fossil $\mathrm{CH}_{4}$, and 265 for $\mathrm{N}_{2} \mathrm{O}$ (IPCC, 2013). Emission of GHG were expressed per tonne of fat- and protein-corrected milk (FPCM). To express emissions per tonne of FPCM, we used economic allocation to allocate emissions between milk and meat.

\section{Setup of the Analysis}

The starting point for model was an average dairy farm in 2014 (i.e., before quota abolition), applying day grazing. Input data, including milk quota, farmland, barn capacity, labor availability, and dairy cow production traits, were based on national statistics (CBS, 2015; LEI, 2015) and are included in Table 2. Milk price was based on expectations for 2014-2024 according to KWIN-V (2014) and is included in Table 2. Maximum grass intake during grazing was assumed 10 $\mathrm{kg}$ of DM/cow per day (Taweel et al., 2004; Abrahamse et al., 2009; Kennedy et al., 2009). We used the linear 
Table 2. Model input data to simulate an average Dutch dairy farm before quota abolition (situation 2014) and after quota abolition and introduction of the Dairy Act (situation 2016)

\begin{tabular}{|c|c|c|c|}
\hline Item & Unit & Situation 2014 & Situation 2016 \\
\hline Milk quota $^{1}$ & ${\mathrm{t} \mathrm{yr}^{-1}}^{-1}$ & 679 & No \\
\hline Farmland ${ }^{1}$ & ha & 50 & 50 \\
\hline Barn capacity $^{1}$ & No. of cows & 83 & 83 \\
\hline Labor availability $^{1}$ & $\mathrm{~h}$ & 4,000 & 4,000 \\
\hline Milk production ${ }^{2}$ & $\mathrm{~kg} \operatorname{cow}^{-1} \mathrm{yr}^{-1}$ & 8,160 & 8,160 \\
\hline Fat content ${ }^{1}$ & $\%$ & 4.40 & 4.40 \\
\hline Protein content ${ }^{1}$ & $\%$ & 3.50 & 3.50 \\
\hline Milk price ${ }^{3}$ & $€ \mathrm{t}^{-1}$ & 355 & 355 \\
\hline Replacement rate $^{1}$ & $\%$ & 26.4 & 26.4 \\
\hline Dairy Act ${ }^{1}$ & & No & Yes \\
\hline Reference surplus 2013 & $\mathrm{~kg}$ of phosphate $\mathrm{yr}^{-1}$ & - & 800 \\
\hline Reference surplus 2014 & $\mathrm{~kg}$ of phosphate $\mathrm{yr}^{-1}$ & - & 1,142 \\
\hline Phosphate quota & $\mathrm{kg}$ of phosphate $\mathrm{yr}^{-1}$ & - & 4,841 \\
\hline Manure disposal $^{3}$ & $€ \mathrm{t}^{-1} \mathrm{yr}^{-1}$ & 9 & 9 \\
\hline Manure processing ${ }^{3}$ & $€ \mathrm{t}^{-1} \mathrm{yr}^{-1}$ & 13 & 13 \\
\hline Extra labor ${ }^{3}$ & $€ \mathrm{~h}^{-1}$ & 17 & 17 \\
\hline Extra barn capacity ${ }^{3}$ & $€ \operatorname{cow}^{-1} \mathrm{yr}^{-1}$ & - & 558 \\
\hline Extra farmland ${ }^{3}$ & $€ \mathrm{ha}^{-1} \mathrm{yr}^{-1}$ & - & 1,187 \\
\hline Extra phosphate quota ${ }^{3}$ & $€ \mathrm{~kg}$ of phosphate $\mathrm{yr}^{-1}$ & - & 2.10 \\
\hline
\end{tabular}

programming model for economic optimization of this farm before quota abolition (i.e., situation 2014).

Then, we removed the milk quota from the model and included the Dairy Act. We used economic optimization again to determine the new optimal farm plan (i.e., situation 2016) and evaluate changes in farm structure, management, labor income, nitrogen and phosphate surpluses, and GHG emissions resulting from the policy changes. Input data to optimize the situation after quota abolition (situation 2016) are included in Table 2. The reference phosphate surplus in 2013 and the phosphate surplus in 2014 were based on the average number of cows on a Dutch dairy farm in the corresponding years according to national statistics (CBS, 2015). The phosphate quota was based on the average number of cows on a Dutch dairy farm in 2014, as the average number of cows in 2015 was not available yet (CBS, 2015). We allowed $70 \%$ of the reference phosphate surplus in 2013 to be disposed to another farm without processing. The price of liquid manure (slurry) disposal without processing was assumed to be $€ 9 / \mathrm{t}$, and the additional price of processing was assumed to be $€ 4 / \mathrm{t}$ (KWIN-V, 2014). Purchase of farmland, barn capacity, and phosphate quota was optional (Table 2). Costs of additional land that can be either used for grass or maize were assumed to be $€ 1,187 /$ ha per yr, based on the current average Dutch land price of $€ 46,000 /$ ha (KWIN-V, 2014), an interest rate of $4.5 \%$ (KWIN-V, 2014 ), and an inflation rate of $1.92 \%$ over the past 5 yr (CBS, 2015). The price of additional labor was assumed to be $€ 17 / \mathrm{h}$, and the price of additional barn capacity was assumed to be $€ 558 /$ cow place, including young stock. Costs of phosphate quota were assumed to be $€ 2.10 / \mathrm{kg}$ of phosphate, based on current prices for quota in the pig sector (i.e., €70/pig, producing 7.4 $\mathrm{kg}$ of phosphate), a depreciation period of $5 \mathrm{yr}$, and an interest rate of $4.5 \%$ (KWIN-V, 2014).

\section{Sensitivity Analyses}

Assumptions on production parameters and market factors can influence results. We performed a sensitivity analysis to explore 5 alternative situations for 2016, based on existing ranges of 2 production parameters and 3 market factors. Situation 2016A simulated a farm with a larger barn capacity before quota abolition. We set barn capacity at 120 dairy cows before optimization, based on an increase in barn capacity on Dutch dairy farms toward quota abolition in practice (PBL, 2013). Situation 2016B simulated a highly productive dairy farm; milk yield per cow and grass and maize yield per hectare were increased by $10 \%$ compared with situation 2016. National statistics show a range in average milk production on Dutch dairy farms in 2014 from about $6,697 \mathrm{~kg} \mathrm{cow}^{-1} \mathrm{yr}^{-1}$ (25\% lowest) to $9,616 \mathrm{~kg}$ $\mathrm{cow}^{-1} \mathrm{yr}^{-1}$ (25\% highest) (CRV, 2014). Situation 2016C simulated the effect of lower prices for manure disposal and processing. The price for manure disposal was set at $€ 5 / \mathrm{t}$, and the additional price for manure processing at $€ 3 / \mathrm{t}$, based on price ranges according to KWINV (2014). Situation 2016D simulated the effect of a lower land price. The price of additional land was set at $€ 573 /$ ha per year, based on long-term rental contracts (KWIN-V, 2014). Situation 2016E simulated the effect 
of a higher milk price. The price per tonne of milk was set at $€ 420$, based on the maximum milk price during the last $10 \mathrm{yr}$ (KWIN-V, 2014).

\section{RESULTS AND DISCUSSION}

\section{Farm Structure, Management, and Labor Income Before Quota Abolition}

Farm structure and management of the farm before quota abolition (situation 2014) are shown in Table 3. Farm size was restricted by milk quota. Based on an average milk production of $8,160 \mathrm{~kg} / \mathrm{cow}$ per yr and a replacement rate of $26.4 \%, 83$ dairy cows and 49 young stock were kept (Table 3). Farmland was divided in $80 \%$ grassland and $20 \%$ maize land, which allowed an application of $230 \mathrm{~kg}$ of $\mathrm{N} /$ ha per year from animal manure. In summer, the diet of the dairy cows consisted of $10.0 \mathrm{~kg}(\mathrm{DM})$ of fresh grass, $1.1 \mathrm{~kg}(\mathrm{DM})$ of grass silage, $3.1 \mathrm{~kg}(\mathrm{DM})$ of maize silage, and $5.7 \mathrm{~kg}$ (DM) of concentrates/cow per day. The maximum amount of fresh grass was fed because this was the cheapest feed resource. The amount of grass silage was based on the amount of grass left for ensiling, minus the amount of grass silage fed in winter. Maize silage and concentrates were added to meet the requirements for energy and RDP balance, because these 2 feed restrictions appeared to be binding. In winter, the diet consisted of $7.3 \mathrm{~kg}$ (DM) of grass silage, $3.3 \mathrm{~kg}$ (DM) of maize silage, and $6.2 \mathrm{~kg}(\mathrm{DM})$ of concentrates/cow per day. Requirements for energy, RDP balance, and true protein digested in the small intestine were met. Purchased feed consisted of $193 \mathrm{t}$ of DM concentrates, and external labor requirement was $42 \mathrm{~h} / \mathrm{yr}$. There was no manure surplus, which meant that all the manure was applied on the farmland. The total phosphate excretion of $3,990 \mathrm{~kg}$ was lower than the quota of 4,841 $\mathrm{kg}$. This was explained by the fact that the phosphate quota was based on standard excretion factors, whereas phosphate excretion in the model was based on farmspecific excretion. In addition, the phosphate quota was based on 89 dairy cows (CBS, 2015), whereas only 83 cows were needed to fulfill the milk quota. The difference in the number of cows between an average farm in practice and our model farm is explained by the fact that in 2014, many farmers produced above their milk quota in anticipation of the quota abolition.

Labor income on the farm before quota abolition was $€ 10,343 /$ yr (Table 4). Revenues could be attributed primarily to milk sales, and costs to feed purchases and fixed costs for buildings and machinery. The net farm income for this type of farm would generally be $€ 20,000 / y r$ higher than the labor income because of owner equity.

\section{Farm Structure, Management, and Labor Income After Quota Abolition}

Farm structure and management of the farm after quota abolition and introduction of the Dairy Act (situation 2016) are shown in Table 3. Farm size was no longer restricted by milk quota but by phosphate application room. On the farm, 87 dairy cows and 51 young stock were kept, and total milk production was $707 \mathrm{t}$ of milk/yr. Due to the limitations of the Dairy Act, increasing the number of cows was only possible when manure was processed or extra land was obtained. However, the revenues of an extra cow did not outweigh the extra costs of manure processing and extra land, in combination with the costs of extra barn capacity, hired labor, and feed. Farm intensity increased from $13,578 \mathrm{~kg}$ of milk/ha before quota abolition to 14,130 $\mathrm{kg}$ of milk/ha after quota abolition. The winter diet was the same as before quota abolition, but the summer diet contained less grass and maize silage per cow per day, as well as more concentrates. With an increase in the number of cows per hectare, less grass silage per cow per day was available in summer. This resulted in a lower RDP balance, compensated for by an increase in concentrates per cow per day. The external labor requirement increased to $127 \mathrm{~h} / \mathrm{yr}$. With a total phosphate excretion of $4,200 \mathrm{~kg} / \mathrm{yr}$, phosphate quota was still not restricting. The labor income of this farm was $€ 10,848$ (Table 4), only slightly higher than before quota abolition.

\section{Sensitivity Analyses}

Table 5 shows the results of the sensitivity analyses. Situation 2016A represented a farm that increased its barn capacity before quota abolition to 120 dairy cows plus young stock. Results showed that the available barn capacity was fully used (Table 5). Increasing the number of cows beyond the available barn capacity was not economically attractive under current prices. Six additional hectares of farmland were obtained to increase the phosphate application room compared with situation 2016. The percentage of grassland remained $80 \%$, which allowed for derogation. The number of cows per hectare was restricted by both the nitrogen and phosphate application room, resulting in an intensity of $17,440 \mathrm{~kg}$ of milk/ha. To meet the feeding requirements of the dairy herd, $94 \mathrm{t}(\mathrm{DM})$ of maize silage and $316 \mathrm{t}$ (DM) of concentrates were purchased. Total phosphate excretion was $5,884 \mathrm{~kg} / \mathrm{yr}$. As a result, $1,043 \mathrm{~kg}$ of extra phosphate quota was purchased. The possibility of disposing $70 \%$ of the phosphate surplus from 2013 was maximally used. In addition, $608 \mathrm{~kg}$ of phosphate was processed. Due to higher fixed costs related to increased barn capacity, labor income was only $€ 2,005 / \mathrm{yr}$. 
Table 3. Farm structure and management of an average Dutch dairy farm before quota abolition (situation 2014) and after quota abolition and introduction of the Dairy Act (situation 2016)

\begin{tabular}{|c|c|c|c|}
\hline Item & Unit & Situation 2014 & Situation 2016 \\
\hline \multicolumn{4}{|l|}{ Farm structure } \\
\hline Dairy cows & No. & 83 & 87 \\
\hline Total farmland & ha & 50 & 50 \\
\hline Grassland & $\%$ & 80 & 80 \\
\hline $\mathrm{N}_{\min }$ application on grassland ${ }^{1}$ & $\mathrm{~kg}$ of $\mathrm{N} \mathrm{ha} \mathrm{yr}^{-1}$ & 225 & 225 \\
\hline \multicolumn{4}{|l|}{ Diet dairy cows: summer } \\
\hline Grass & & 10.0 & 10.0 \\
\hline Grass silage & & 1.1 & 0.3 \\
\hline Maize silage & & 3.1 & 2.7 \\
\hline Concentrates & & 5.7 & 6.7 \\
\hline Diet restricted by ${ }^{2}$ & & $\mathrm{E}, \mathrm{R}, \mathrm{G}$ & $\mathrm{E}, \mathrm{R}, \mathrm{G}$ \\
\hline \multicolumn{4}{|l|}{ Diet dairy cows: winter } \\
\hline Purchased maize silage & $\mathrm{t}$ of $\mathrm{DM} \mathrm{yr}^{-1}$ & 0 & 0 \\
\hline Purchased concentrates & $\mathrm{t}$ of $\mathrm{DM} \mathrm{yr}-1$ & 193 & 218 \\
\hline Hired labor & $\mathrm{h}$ & 42 & 127 \\
\hline \multicolumn{4}{|l|}{ Manure management } \\
\hline Manure application restricted by & & - & Phosphate \\
\hline Total excretion & $\mathrm{kg}$ of phosphate $\mathrm{yr}^{-1}$ & 3,990 & 4,200 \\
\hline Extra phosphate quota & $\mathrm{kg}$ of phosphate $\mathrm{yr}^{-1}$ & - & 0 \\
\hline
\end{tabular}

Situation 2016B represented a highly productive farm. Results showed a farm size of 107 dairy cows, and no additional land was obtained. Based on the Dairy Act, a further increase in the number of cows would require additional land. Similar to situation 2016A, the number of dairy cows per hectare was restricted by the total nitrogen and phosphate application room. Due to higher productivity, however, farm intensity was 19,191 $\mathrm{kg}$ of milk/ha. Labor income was €32,093/yr. Results showed that farm productivity could considerably increase labor income.

In situation $2016 \mathrm{C}$, the costs of manure processing were decreased to $€ 8 / \mathrm{t}$ of manure. Results showed a farm size of 100 dairy cows, and no additional land was obtained. The number of dairy cows was restricted by the phosphate quota. Again, the number of cows was higher than the number of cows used to calculate the phosphate quota, due to lower farm-specific excretion

Table 4. Labor income $(€ /$ yr) for an average Dutch dairy farm before quota abolition (situation 2014) and after quota abolition and introduction of the Dairy Act (situation 2016)

\begin{tabular}{lrc}
\hline Item & Situation 2014 & Situation 2016 \\
\hline Revenues & & \\
Milk & 241,037 & 250,843 \\
Livestock sales/purchases & 27,430 & 28,546 \\
Government payments & 13,500 & 13,500 \\
Variable costs & 47,877 & 54,210 \\
Concentrate purchases & 0 & 0 \\
Roughage purchases & 52,983 & 52,182 \\
On-farm roughage production & 0 & 0 \\
Manure disposal and processing & 714 & 2,145 \\
Hired labor & 36,378 & 37,858 \\
Other & 133,672 & 135,646 \\
Fixed costs & 10,343 & 10,848 \\
Labor income & & \\
\hline
\end{tabular}


Table 5. Farm structure and management for an average Dutch dairy farm with grazing in sensitivity analyses A to E for situation 2016

\begin{tabular}{|c|c|c|c|c|c|c|}
\hline Item & Unit & $\begin{array}{l}\text { Situation } 2016 \mathrm{~A} \text { : } \\
\text { Increased barn } \\
\text { capacity }\end{array}$ & $\begin{array}{l}\text { Situation } 2016 \mathrm{~B} \text { : } \\
\text { Higher field and cow } \\
\text { productivity }\end{array}$ & $\begin{array}{l}\text { Situation } 2016 \mathrm{C}: \\
\text { Lower manure disposal } \\
\text { and processing prices }\end{array}$ & $\begin{array}{l}\text { Situation } 2016 \text { D: } \\
\text { Lower land price }\end{array}$ & $\begin{array}{l}\text { Situation } 2016 \mathrm{E} \text { : } \\
\text { Higher milk price }\end{array}$ \\
\hline \multicolumn{7}{|l|}{ Farm structure } \\
\hline Dairy cows & No. & 120 & 107 & 100 & 100 & 180 \\
\hline Young stock & No. & 71 & 63 & 59 & 59 & 106 \\
\hline Total milk production & ${\mathrm{t} y \mathrm{r}^{-1}}$ & 979 & 961 & 817 & 814 & 1,469 \\
\hline Total farmland & ha & 56 & 50 & 50 & 58 & 84 \\
\hline Grassland & $\%$ & 80 & 80 & 80 & 80 & 80 \\
\hline Maize land & $\%$ & 20 & 20 & 20 & 20 & 20 \\
\hline Farm intensity & $\mathrm{kg}$ of milk ha ${ }^{-1}$ & 17,440 & 19,191 & 16,331 & 14,130 & 17,440 \\
\hline \multicolumn{7}{|l|}{ External inputs } \\
\hline Purchased maize silage & $\mathrm{t}$ of $\mathrm{DM} \mathrm{yr} \mathrm{r}^{-1}$ & 94 & 80 & 48 & 0 & 141 \\
\hline Purchased concentrates & $\mathrm{t}$ of $\mathrm{DM} \mathrm{yr}^{-1}$ & 316 & 290 & 263 & 251 & 474 \\
\hline Hired labor & $\mathrm{h} \mathrm{yr} \mathrm{r}^{-1}$ & 1,064 & 694 & 480 & 556 & 2,937 \\
\hline Nitrogen application on grassland & $\mathrm{kg}$ of $\mathrm{N} \mathrm{ha}{ }^{-1} \mathrm{yr}^{-1}$ & 250 & 250 & 250 & 225 & 250 \\
\hline \multicolumn{7}{|l|}{ Manure management } \\
\hline Manure application restricted by ${ }^{1}$ & & $\mathrm{tN}, \mathrm{P}$ & $\mathrm{tN}, \mathrm{P}$ & $\mathrm{tN}$ & $\mathrm{P}$ & $\mathrm{tN}, \mathrm{P}$ \\
\hline Total phosphate excretion & $\mathrm{kg}$ of phosphate $\mathrm{yr}^{-1}$ & 5,884 & 5,376 & 4,841 & 4,841 & 8,826 \\
\hline Applied on own land & $\mathrm{kg}$ of phosphate $\mathrm{yr}^{-1}$ & 4,717 & 4,208 & 3,857 & 4,841 & 7,075 \\
\hline Manure disposal & $\mathrm{kg}$ of phosphate $\mathrm{yr}^{-1}$ & 560 & 560 & 560 & 0 & 560 \\
\hline Manure processing & $\mathrm{kg}$ of phosphate $\mathrm{yr}^{-1}$ & 608 & 608 & 424 & 0 & 1,191 \\
\hline Purchased phosphate quota & $\mathrm{kg}$ of phosphate $\mathrm{yr}^{-1}$ & 1,043 & 534 & 0 & 0 & 3,985 \\
\hline Labor income & $€ \mathrm{yr}^{-1}$ & 2,005 & 32,093 & 11,162 & 14,240 & 80,489 \\
\hline
\end{tabular}

${ }^{1} \mathrm{tN}=$ total mineral nitrogen, $\mathrm{P}=$ phosphate. 
values compared with standard values. Labor income was $€ 11,162 /$ yr.

In situation $2016 \mathrm{D}$, land costs were decreased to $€ 573 /$ ha. Results showed a farm size of 100 dairy cows. Similar to situation 2016C, the number of dairy cows was restricted by the phosphate quota. In this situation, however, 8 additional hectares of land were obtained to apply all manure on farmland. The number of cows per hectare was restricted by the phosphate application room.

In situation $2016 \mathrm{E}$, the milk price was increased to $€ 420 /$ t. Results showed a farm size of 180 dairy cows and 84 ha of land. The number of cows was restricted by machinery capacity, which could be solved quite easily in practice. Reaching this artificial maximum implied that the farm could experience unlimited growth when external inputs such as labor, land, barn capacity, and feed were available without limits at current prices. The number of cows per hectare was restricted by the nitrogen and phosphate application room, resulting in a farm intensity of $17,440 \mathrm{~kg}$ of milk/ha. The external labor requirement was $2,937 \mathrm{~h} / \mathrm{yr}$. Total phosphate excretion was $8,826 \mathrm{~kg} / \mathrm{yr}$, which means that $3,985 \mathrm{~kg}$ of phosphate was purchased. Labor income was €80,489/ yr.

\section{Environmental Impact}

Figure 2 shows the nitrogen and phosphate surpluses per hectare of the farm before (situation 2014) and after (situation 2016-2016E) quota abolition. The nitrogen surpluses per hectare after quota abolition (192 to 213 $\mathrm{kg} / \mathrm{ha}$ ) were higher than before quota abolition (186 $\mathrm{kg} / \mathrm{ha}$ ). The level of nitrogen surplus was highly related to farm intensity, except for situation 2016B. Situation 2016B had the highest intensity but a relatively low nitrogen surplus, related to higher farm productivity, meaning more efficient use of inputs.

The phosphate surpluses after quota abolition varied from 3 to $11 \mathrm{~kg} / \mathrm{ha}$, whereas the phosphate surplus before quota abolition was $7 \mathrm{~kg} / \mathrm{ha}$. The lower phosphate surpluses after quota abolition in situation 2016B were explained by higher farm productivity and, in situation 2016C, by the relatively large amount of phosphate disposal and processing.

Figure 3 shows the results for GHG emissions per tonne of FPCM for the farm before (situation 2014) and after (situation 2016-2016E) quota abolition. The GHG emissions per tonne of FPCM after quota abolition (range from 938 to $1,001 \mathrm{~kg}$ of $\mathrm{CO}_{2} \mathrm{eq} / \mathrm{t}$ of $\mathrm{FPCM}$ ) were in the same range as before quota abolition $(985$ $\mathrm{kg}$ of $\mathrm{CO}_{2} \mathrm{eq} / \mathrm{t}$ of FPCM). Per tonne of FPCM produced, the increase in off-farm emissions from concentrate production was offset by the decrease in on-farm emissions related to enteric fermentation and roughage production. Situation 2016B resulted in the lowest GHG emissions. This can be explained by an increase in farm productivity, resulting in, for example, dilution of GHG emissions related to maintenance.

Taking into account the increase in total milk production, total GHG emissions (i.e., from cradle to farm gate) at the farm level increased from $707,385 \mathrm{~kg}$ of $\mathrm{CO}_{2} \mathrm{eq} / \mathrm{yr}$ before quota abolition to $738,706 \mathrm{~kg}$ of $\mathrm{CO}_{2} \mathrm{eq} / \mathrm{yr}$ after quota abolition. This increase of $4.4 \%$ implied an almost linear increase of GHG emission with the number of cows.

\section{General Discussion}

Milk production in the Netherlands has increased in recent years because farmers have anticipated the end of the milk quota system, but it is unlikely that the volume of milk production in the Netherlands will undergo further substantial increases under the new manure policy. Due to additional costs related to manure processing, additional farmland, and the phosphate quota, the costs of production will probably increase rather than decrease. In addition, the possibility of obtaining additional land varies across the Netherlands, limiting the expansion of dairy farms in areas where farmland is scarce. Most importantly, the phosphate quota will restrict the growth of the national dairy herd. It is unlikely that the Netherlands will become more competitive or supply more milk to the world milk market.

Our review of developments in manure legislation shows continuous changes and uncertainties in the transitions from old to new regulations. This creates risks for dairy farmers in anticipating developments in the dairy sector. In addition to policy risks, dairy farm-

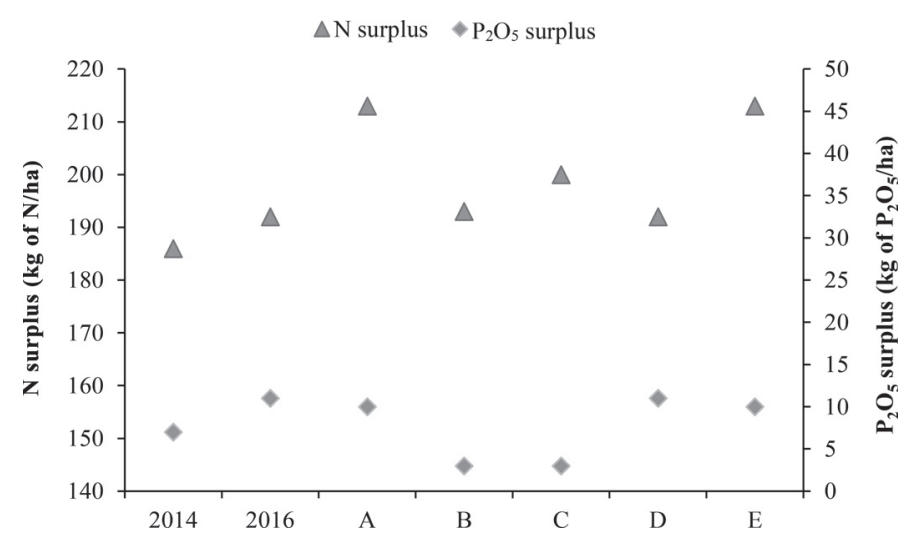

Figure 2. Nitrogen $(\mathrm{N})$ and phosphate $\left(\mathrm{P}_{2} \mathrm{O}_{5}\right)$ farm surpluses per hectare for an average Dutch dairy farm before quota abolition (2014) and after quota abolition (2016). Results A to E are variants of 2016 scenario: $\mathrm{A}=$ increased barn capacity, $\mathrm{B}=$ higher field and cow productivity, $\mathrm{C}=$ low manure disposal and processing prices, $\mathrm{D}=$ low land price, and $\mathrm{E}=$ higher milk price. 
8394

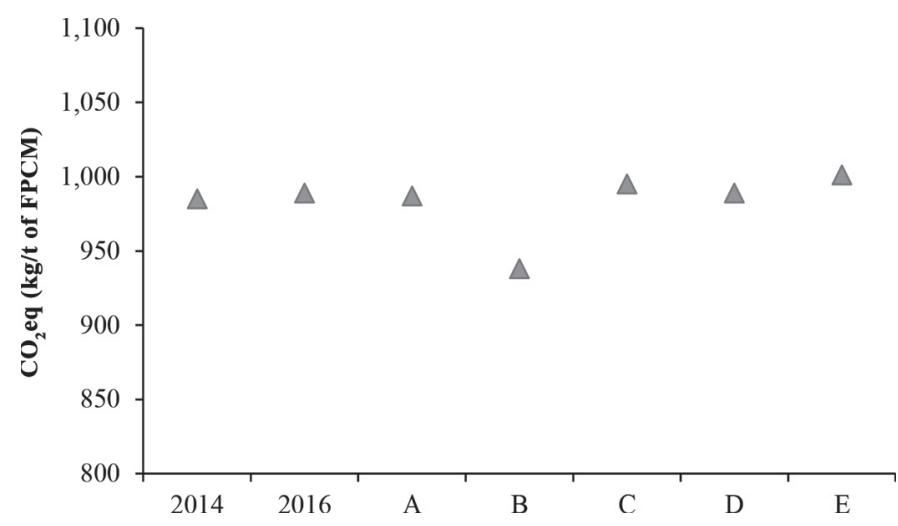

Figure 3. Greenhouse gas emissions $\left[\mathrm{kg}\right.$ of $\mathrm{CO}_{2}$ equivalents $\left(\mathrm{CO}_{2}-\right.$ eq) per tonne of fat- and protein-corrected milk (FPCM)] for an average Dutch dairy farm before quota abolition (2014) and after quota abolition (2016). Results A to E are variants of scenario: A = increased barn capacity, $\mathrm{B}=$ higher field and cow productivity, $\mathrm{C}=$ low manure disposal and processing prices, $\mathrm{D}=$ low land price, and $\mathrm{E}=$ higher milk price.

ers face market risks. The alternative situation, with a high milk price, showed a large effect of milk price on income. In addition, the volatility of the milk price in the $\mathrm{EU}$ is increasing due to decreasing governmental intervention (Holmer, 2015).

Increasing phosphate efficiency at the farm level offers the potential to increase milk production within the limits of the phosphate quota. Balancing phosphorus levels in the diet with the phosphorus requirements of the cow, for example, offers the potential to decrease phosphate excretion. Based on the current analysis, cows were found to be fed $37 \%$ above phosphorus requirements in winter and $42 \%$ in summer, indicating potential for improvement.

So far, the costs for extra phosphate quota are unclear. Based on current prices for quota in the pig sector, we assumed yearly costs of $€ 2.10 / \mathrm{kg}$ of phosphate. This followed from a total investment of $€ 413 /$ dairy cow, a depreciation period of $5 \mathrm{yr}$, and an interest rate of $4.5 \%$ (KWIN-V, 2014). Further analysis of the results showed that for the situations with the increased barn capacity and with the high milk price, phosphate quota would be purchased until yearly costs reach a level of about $€ 11 / \mathrm{kg}$ of phosphate, which equaled an investment in phosphate quota of around €2,000/dairy cow.

In agreement with Daatselaar et al. (2015), nitrogen surplus per hectare increased with an increase in farm intensity. Nutrient surpluses in this study were at the lower range of nutrient surpluses found on an average Dutch dairy farm in practice (LEI, 2015). Differences can be explained by the use of an optimization model, which may increase farm efficiency, and by the fact that most recent data on nutrient surpluses of actual farms (LEI, 2015) are from 2011. Our results showed higher GHG emissions per tonne of FPCM than Van Middelaar et al. (2014), which can be explained by the update of emission factors for concentrate production (FeedPrint, 2015) and an update of the global warming potentials of $\mathrm{CH}_{4}$ and $\mathrm{N}_{2} \mathrm{O}$ (IPCC, 2013).

\section{CONCLUSIONS}

Several factors have limited the growth of Dutch dairy farms after quota abolition. Based on current prices, increasing the number of cows is profitable up to the level that requires manure processing or additional land to comply with the new manure policy. This results in an increase in the number of cows and in farm intensity of about $4 \%$ compared to before quota abolition. When costs of manure processing or of land decrease, phosphate quota becomes a limiting factor. Within the phosphate quota, however, farm intensity can increase about $20 \%$ by increasing the efficiency of phosphate use. If milk prices increased to the high level of 2013-2014, farms could grow unlimited, provided that the availability of external inputs such as labor, land, barn capacity, feed, and phosphate quota at current prices were also unlimited. Results showed that the milk quota abolition, accompanied by the Dairy Act, will slightly increase nutrient losses per hectare, due to an increase in farm intensity. Greenhouse gas emissions per unit of milk will barely change, so at a given milk production per cow, total GHG emissions will increase linearly with an increase in the number of cows.

\section{ACKNOWLEDGMENTS}

We thank the Province of Fryslân (the Netherlands) and Melkveefonds (LTO Nederland and Wageningen UR Livestock Research; the Netherlands) for financially supporting this research.

\section{REFERENCES}

Abrahamse, P., S. Tamminga, and J. Dijkstra. 2009. Effect of daily movement of dairy cattle to fresh grass in morning or afternoon on intake, grazing behaviour, rumen fermentation and milk production. J. Agric. Sci. 147:721-730. http://dx.doi.org/10.1017/ S0021859609990153.

Berentsen, P. B. M., and G. W. J. Giesen. 1995. An environmentaleconomic model at farm level to analyse institutional and technical change in dairy farming. Agric. Syst. 49:153-175. http://dx.doi. org /10.1016/0308-521X(94)00042-P.

Berentsen, P. B. M., G. W. J. Giesen, and S. C. Verduyn. 1992. Manure legislation effects on income and on N, P and $\mathrm{K}$ losses in dairy farming. Livest. Prod. Sci. 31:43-56. http://dx.doi. org/10.1016/0301-6226(92)90051-5.

Berentsen, P. B. M., and M. Tiessink. 2003. Potential effects of accumulating environmental policies on Dutch dairy farms. J. Dairy Sci. 86:1019-1028. http://dx.doi.org/10.3168/jds.S00220302(03)73685-6. 
CBS. 2013. CBS Statline. Accessed Mar. 25, 2013. http://statline.cbs. $\mathrm{nl} /$ Statweb/dome/?LA=en.

CBS. 2015. CBS Statline. Accessed July 04, 2015. http://statline.cbs. $\mathrm{nl} /$ Statweb/dome/?LA=en.

CRV. 2014. Jaarstatistieken 2014. Dutch milk production statistics 2014. Accessed June 05, 2015. https://www.crv4all.nl/downloads/ crv/jaarverslag/.

Daatselaar, C. H., J. R. Reijs, J. Oenema, G. J. Doornewaard, and H. F. Aarts. 2015. Variation in nitrogen use efficiencies on Dutch dairy farms. J. Sci. Food Agric. 95:3055-3058. http://dx.doi. org $/ 10.1002 /$ jsfa. 7250 .

De Mol, R. M., and M. A. Hilhorst. 2003. Methaan-, lachgas- en ammoniakemissies bij productie, opslag en transport van mest. Emissions of methane, nitrous oxide and ammonia occuring during production, storage and transport of manure. Report 2003-03. Institute of Agricultural and Environmental Engineering, Wageningen, the Netherlands.

EU. 1991. Council Directive concerning the protection of waters against pollution caused by nitrates from agricultural sources. In Official Journal of the European Communities. Document 91/676/ EEC, Dec. 12, 1991. Council of the European Union. http://data. europa.eu/eli/dir/1991/676/oj.

EU. 2003. Judgment of the European Court about failure of a Member State to fulfil its obligations according to the Nitrates Directive (91/676/EEC). Case C-322/00, Oct. 2, 2003. Court of Justice, Commission of the European Communities v Kingdom of the Netherlands. http://publications.europa.eu/s/bg1S.

EU. 2010. Commission decision concerning the protection of waters against pollution caused by nitrates from agricultural sources. In Official Journal of the European Union. Document C(2010) 606, Feb. 5, 2010. European Commission, Brussels, Belgium. http:// data.europa.eu/eli/dec/2010/65(1)/oj.

EU. 2015. The end of the milk quotas. European commission, Agriculture and Rural Development. Accessed Oct. 27, 2015. http:// ec.europa.eu/agriculture/milk-quota-end/index_en.htm.

FeedPrint. 2015. FeedPrint: calculate CO2 per kilogram meat, milk or eggs. Accessed Dec. 9, 2015. http://www.wageningenur.nl/en/ show/Feedprint.htm.

Gerber, P. J., H. Steinfeld, B. Henderson, A. Mottet, C. Opio, J. Dijkman, A. Falcucci, and G. Tempio. 2013. Tackling Climate Change Through Livestock - A Global Assessment of Emissions and Mitigation Opportunities. Food and Agriculture Organization of the United Nations, Rome, Italy.

Holmer, I. 2015. Analysis of price fluctuations in Dutch dairy farming. MS Thesis. Business Economics group, Wageningen Univ., Wageningen, the Netherlands.

IPCC. 2006. IPCC Guidelines for National Greenhouse Gas Inventories. Volume 4: Agriculture, Forestry and Other Land Use. Prepared by the National Greenhouse Gas Inventories Programme. H. S. Eggleston, L. Buendia, K. Miwa, T. Ngara, and K. Tanabe, ed. IGES, Kanagawa, Japan.

IPCC. 2013. Climate Change 2013: The Physical Science Basis. Working Group I Contribution to the Fifth Assessment Report of the Intergovernmental Panel on Climate Change. T. F. Stocker, D. Qin, G.-K. Plattner, M. Tignor, S. K. Allen, J. Boschung, A. Nauels, Y. Xia, V. Bex, and P. M. Midgley, ed. Cambridge University Press, Cambridge, UK.

Jarrige, R. 1988. Alimentation des bovins, ovins et caprins. Feeding of cattle, sheep and goats. Institut National de la Recherche Agronomique, Paris, France.

Kempen, M., P. Witzke, I. Pérez Domínguez, T. Jansson, and P. Sckokai. 2011. Economic and environmental impacts of milk quota reform in Europe. J. Policy Model. 33:29-52. http://dx.doi. org/10.1016/j.jpolmod.2010.10.007.

Kennedy, E., M. McEvoy, J. P. Murphy, and M. O'Donovan. 2009. Effect of restricted access time to pasture on dairy cow milk production, grazing behavior, and dry matter intake. J. Dairy Sci. 92:168-176. http://dx.doi.org/10.3168/jds.2008-1091.

KWIN-V. 2014. Kwantitatieve Informative Veehouderij 2014-2015. Quantitative Information Livestock Farming 2014-2015. Wageningen UR Livestock Research, Wageningen, the Netherlands.
LEI. 2015. Dutch FADN, Agriculture. Accessed Dec. 11, 2015. http:// www.agrimatie.nl/Data.aspx.

Lips, M., and P. Rieder. 2005. Abolition of raw milk quota in the European Union: A CGE analysis at the member country level. J. Agric. Econ. 56:1-17. http://dx.doi.org/10.1111/j.1477-9552.2005. tb00119.x.

Nevedi. 2012. De Nederlandse Vereniging Diervoederindustrie. The Dutch Feed Industry Association. Lineaire programmeringen rundvee-, varkens en pluimveevoerders. Linear Programming Cattle-, Pig, and Poultry Feed. Schothorst Feed Research B.V. Report Nr 5-12, year 2012.

Nevedi. 2013. De Nederlandse Vereniging Diervoederindustrie. The Dutch Feed Industry Association. Lineaire programmeringen rundvee-, varkens en pluimveevoerders. Linear Programming Cattle-, Pig, and Poultry Feed. Schothorst Feed Research B.V. Report Nr 1-12, year 2013.

Nevedi. 2014. De Nederlandse Vereniging Diervoederindustrie. The Dutch Feed Industry Association. Lineaire programmeringen rundvee-, varkens en pluimveevoerders. Linear Programming Cattle-, Pig, and Poultry Feed. Schothorst Feed Research B.V. Report Nr 1-12, year 2014.

Nevedi. 2015. De Nederlandse Vereniging Diervoederindustrie. The Dutch Feed Industry Association. Lineaire programmeringen rundvee-, varkens en pluimveevoerders. Linear Programming Cattle-, Pig, and Poultry Feed. Schothorst Feed Research B.V. Report Nr 1-5, year 2015.

Nitraatrichtlijn. 2014. Vijfde Nederlandse Actieprogramma Nitraatrichtlijn (2014-2017). Fifth Dutch Action Program Nitrates Directive (2014-2017). Dutch manure legislation for the years 2014-2017. Ministry of Economic Affairs, The Hague, the Netherlands.

Oenema, O. and P. B. M. Berentsen. 2005. Manure Policy and MINAS: Regulating Nitrogen and Phosphorus Surpluses in Agriculture of the Netherlands. OECD Environment Programme. http://www.oecd. org/officialdocuments/publicdisplaydocumentpdf/?cote=COM/ $\mathrm{ENV} / \mathrm{EPOC} / \mathrm{CTPA} / \mathrm{CFA}(2004) 67 /$ FINAL\&docLanguage $=$ En .

Oenema, O., H. Kros, and W. de Vries. 2003. Approaches and uncertainties in nutrient budgets: Implications for nutrient management and environmental policies. Eur. J. Agron. 20:3-16. http://dx.doi. org/10.1016/S1161-0301(03)00067-4.

Oenema, O., L. Van Liere, and O. Schoumans. 2005. Effects of lowering nitrogen and phosphorus surpluses in agriculture on the quality of groundwater and surface water in the Netherlands. J. Hydrol. (Amst.) 304:289-301. http://dx.doi.org/10.1016/j. jhydrol.2004.07.044.

PBL. 2013. Bijlage 7: Uitbreidingsruimte veehouderij binnen provinciaal en gemeentelijk milieu en ruimtelijk beleid. Appendix 7: Expansion potential of livestock farms. In Ex ante evaluatie mestbeleid 2013. Ex Ante Evaluation Manure Policy 2013. H. Ullenbroeck and L. T. M. Lamers, ed. Netherlands Environmental Assessment Agency, the Hague, the Netherlands.

Rijksoverheid. 2015. Algemene Maatregel van Bestuur: besluit tot wijziging van het Uitvoeringsbesluit Meststoffenwet ten behoeve van een verantwoorde groei van de melkveehouderij. Order of council: decision to change manure policy to support land-based growth of the dairy sector. Ministry of Economic Affairs, The Hague, the Netherlands.

RVO. 2014. Standard excretion factors according to manure policy 2014-2017. Accessed Nov. 24, 2014. http://www.rvo. $\mathrm{nl} /$ onderwerpen/agrarisch-ondernemen/mest-en-grond/mest/ tabellen-en-publicaties/tabellen-en-normen.

Sharpley, A. N. 1995. Dependence of runoff phosphorus on extractable soil phosphorus. J. Environ. Qual. 24:920-926. http://dx.doi. org/10.2134/jeq1995.00472425002400050020x.

Tamminga, S., W. M. Van Straalen, A. P. J. Subnel, R. G. M. Meijer, A. Steg, C. J. G. Wever, and M. C. Blok. 1994. The Dutch protein evaluation system: the DVE/OEB-system. Livest. Prod. Sci. 40:139-155. http://dx.doi.org/10.1016/0301-6226(94)90043-4.

Taweel, H. Z., B. M. Tas, J. Dijkstra, and S. Tamminga. 2004. Intake regulation and grazing behavior of dairy cows under continuous 
stocking. J. Dairy Sci. 87:3417-3427. http://dx.doi.org/10.3168/ jds.S0022-0302(04)73477-3.

Van Middelaar, C. E., P. B. M. Berentsen, J. Dijkstra, and I. J. M. De Boer. 2013. Evaluation of a feeding strategy to reduce greenhouse gas emissions from dairy farming: The level of analysis matters. Agric. Syst. 121:9-22. http://dx.doi.org/10.1016/j.agsy.2013.05.009.

Van Middelaar, C. E., J. Dijkstra, P. B. M. Berentsen, and I. J. M. De Boer. 2014. Cost-effectiveness of feeding strategies to reduce green- house gas emissions from dairy farming. J. Dairy Sci. 97:24272439. http://dx.doi.org/10.3168/jds.2013-7648.

Weidema, B. P., C. Bauer, R. Hischier, C. Mutel, T. Nemecek, J. Reinhard, C. O. Vadenbo, and G. Wernet. 2013. Overview and Methodology. Data Quality Guideline for the Ecoinvent Database Version 3. Ecoinvent Report 1(v3). Ecoinvent Centre, St. Gallen, Switzerland.

\section{APPENDIX}

Table A1. Dutch phosphate excretion values for 2015 to 2017 (RVO, 2014)

\begin{tabular}{|c|c|c|}
\hline Item & $\begin{array}{c}\text { Milk yield } \\
\left(\mathrm{kg} \text { of milk } \mathrm{yr}^{-1}\right)\end{array}$ & $\begin{array}{c}\text { Phosphate excretion } \\
\left(\mathrm{kg} \text { of phosphate animal }{ }^{-1} \mathrm{yr}^{-1}\right)\end{array}$ \\
\hline Dairy cow & $\begin{array}{l}8,125-8,374 \\
8,375-8,624 \\
8,625-8,874\end{array}$ & $\begin{array}{l}41.3 \\
42.0 \\
42.7\end{array}$ \\
\hline $\begin{array}{l}\text { Young stock }<1 \\
\text { Young stock }>1\end{array}$ & & $\begin{array}{r}9.6 \\
21.9\end{array}$ \\
\hline
\end{tabular}

Table A2. Composition of concentrates with 3 protein levels (standard, medium, and high) and corresponding greenhouse gas (GHG) emissions for production of ingredients

\begin{tabular}{|c|c|c|c|c|}
\hline \multirow[b]{2}{*}{ Ingredient } & \multicolumn{3}{|c|}{ Concentrate composition (\%) } & \multirow{2}{*}{$\begin{array}{l}\mathrm{GHG}^{1} \text { (total } \mathrm{CO}_{2} \\
\text { equivalents in } \mathrm{kg} \mathrm{t}^{-1} \text { ) }\end{array}$} \\
\hline & Standard $^{2}$ & Medium $^{2}$ & $\operatorname{High}^{3}$ & \\
\hline Peas & 0.00 & 1.20 & 0.00 & 752 \\
\hline Barley & 0.35 & 0.15 & 0.95 & 388 \\
\hline Soybean meal CF $45-70 \mathrm{CP}<450^{4}$ & 0.14 & 2.95 & 0.00 & 615 \\
\hline Soybean meal CF $45-70 \mathrm{CP}>450^{4}$ & 0.09 & 0.48 & 0.00 & 636 \\
\hline Soybean meal Mervobest & 0.00 & 0.15 & 28.45 & 632 \\
\hline Soybean hulls CF $320-360^{4}$ & 14.52 & 19.47 & 0.00 & 391 \\
\hline Sugarcane molasses SUG $<475^{4}$ & 3.01 & 3.17 & 2.10 & 302 \\
\hline Rape seed, expeller & 0.17 & 0.99 & 0.03 & 528 \\
\hline Rye & 5.15 & 1.10 & 1.84 & 449 \\
\hline Wheat & 2.05 & 2.17 & 0.15 & 390 \\
\hline Palm kernel expeller $\mathrm{CF}<180^{4}$ & 11.80 & 15.95 & 19.33 & 547 \\
\hline Sugarbeet pulp SUG $>200^{4}$ & 3.80 & 4.70 & 6.33 & 366 \\
\hline Maize & 15.87 & 6.57 & 1.48 & 595 \\
\hline Wheat middlings & 11.32 & 2.07 & 2.62 & 249 \\
\hline Soy oil (palm kernel oil) & 0.01 & 0.00 & 0.00 & 3,902 \\
\hline Maize gluten feed CP $200-230^{4}$ & 8.60 & 1.65 & 17.32 & 1,815 \\
\hline Sunflower seed meal CF $>240^{4}$ & 0.67 & 1.00 & 0.22 & 487 \\
\hline Salt & 0.46 & 0.56 & 0.00 & 180 \\
\hline Chalk (finely milled) & 0.99 & 1.28 & 0.00 & 19 \\
\hline Triticale & 5.45 & 6.03 & 1.32 & 587 \\
\hline Palm kernel oil & 0.20 & 0.40 & 0.00 & 3,902 \\
\hline Rape seed, extruded CP $>380^{4}$ & 0.18 & 0.47 & 0.00 & 481 \\
\hline Rape seed, extruded CP $0-380^{4}$ & 1.78 & 5.38 & 0.00 & 477 \\
\hline Rape seed meal & 0.00 & 0.15 & 0.00 & 484 \\
\hline Premix & 1.00 & 1.00 & 1.00 & 4,999 \\
\hline Vinasses sugarbeet $\mathrm{CP}<250^{4}$ & 2.99 & 3.00 & 0.00 & 394 \\
\hline Magnesium oxide & 0.04 & 0.01 & 0.00 & 1,060 \\
\hline Distillers grains and solubles & 9.36 & 17.93 & 7.47 & 296 \\
\hline Citruspulp dehydrated & 0.00 & 0.00 & 7.64 & 747 \\
\hline Fat animal origin & 0.00 & 0.00 & 0.04 & 7,726 \\
\hline Ureum & 0.00 & 0.00 & 1.70 & 1,650 \\
\hline
\end{tabular}

${ }^{1}$ Greenhouse gas emissions for production of ingredients were updated based on FeedPrint (2015).

${ }^{2}$ Concentrate composition of standard and medium protein level were updated based on Nevedi (2012, 2013, 2014, 2015).

${ }^{3}$ Concentrate composition of high protein level was based on Van Middelaar et al. (2014).

${ }^{4} \mathrm{CF}=$ crude fiber, $\mathrm{SUG}=$ sugar $(\mathrm{in} \mathrm{g} / \mathrm{kg})$. 